УДК 536.1

\title{
Review of the specific heat of food models
}

\author{
AYE TUN ${ }^{1}, D . S c$. I. V. BARANOV ${ }^{2}$ \\ 1ayetunitmo@gmail.com, 2ivbaranov@corp.ifmo.ru \\ ITMO University
}

This review proposes the mathematical models widely used by predicting the specific heat of food as a function of temperature. Specific heat is a measure of the energy required to change the temperature of food by one degree. Specific heat of food is essential to determine the heat load imposed on the designing food processes and processing equipment. Above freezing temperature the predicting mathematical model is called specific heat of food. Below freezing temperature the model is called apparent specific heat of food, because of the latent heat involved during phase change. The specific heats of food depend on their composition, structure and temperature. Three ways to obtain value data of specific heat of food such as published data (literature), direct measurement (experiment) and predictive equation (prediction). Predicting of the specific heat of food products was using mathematical models. Mathematical modeling is economical method to determine for predicting of the specific heat of food. Typically, these mathematical models are based on food compositions. The most widely used predicting models are Choi and Okos (1987) model and Schwartzberg (1976) model. These mathematical models are can be used by predicting of the specific heat of food as function of temperature. Other widely used predicting the mathematical models are Seibel (1892), Chen (1985) and Heldman (1975). Seibel (1892) and Heldman and Singh (1981) models do not show the effect of temperature.

Keywords: specific heat, heat load, food compositions, temperature, mathematical models.

Article info:

Received 29/03/2019, accepted 20/06/2019

DOI: $10.17586 / 1606-4313-2019-18-3-82-86$

Article in English

For citation:

Aye Tun, Baranov I. V. Review of the specific heat of food models. Vestnik Mezhdunarodnoi akademii kholoda. 2019. No 3. p. 82-86.

\section{Модели определения удельной теплоемкости продуктов питания}

\author{
АЙ ТУН' ${ }^{1}, \partial-p$ техн. наук И. В. БАРАНОВ ${ }^{2}$ \\ 1ayetunitmo@gmail.com, ${ }^{2}$ ivbaranov@corp.ifmo.ru \\ Университет ИТМО
}

В статье рассмотрены математические модели, иироко используемые для прогнозирования величины удельной теплоемкости продуктов питания, как функции их температуры. Удельная теплоемкость это количество энергии необходимое для изменения температуры продукта на один градус. Ее знание необходимо для определения тепловой нагрузки при проектировании оборудования и процессов в пищевой промышленности. При температуре выше температуры замерзания математическая модель предсказания называется удельной теплоемкостью. При температуре ниже температуры замерзания модель называется кажущейся удельная теплоемкостью изза скрытой теплоты сопряженной с изменением агрегатного состояния. Удельная теплоемкость продуктов питания зависит от их состава пищи, структуры и температуры. Существуют три способа получить данные об удельной теплоемкости: опубликованные источники, прямое измерение в ходе эксперимента и прогнозирование с использованием уравнения. Прогнозирование удельной теплоемкости продуктов питания осуществлялось при помощц математических моделей. Математическое моделирование это экономичный метод для определения прогнозируемой удельной теплоемкости продуктов питания. Обычно эти математические модели основываются на составе пищи. Наиболее часто используемые для прогнозирования модели - это модели Окоса (1987) и Швартцберга (1976). Эти математические модели пересказывают удельную теплоемкость продуктов питания как функцию температуры. Другие иироко используемые модели - это модели Сейбла (1892), Чена (1985) и Хельдмана (1975). Модели Сейбла (1892) и Хельдмана и Синхха (1981) не показывают влияние температуры. Ключевые слова: удельная теплоемкость, тепловая нагрузка, состав пиши, температура, математические модели.

Информация о статье:

Поступила в редакцию 39.03.2019, принята к печати 20.06.2019

DOI: $10.17586 / 1606-4313-2019-18-3-82-86$

Язык статьи - английский

Ссылка для цитирования:

Aye Tun, Baranov I. V. Review of the specific heat of food models. // Вестник Международной академии холода. 2019. № 3. C. 82-86. 


\section{Introduction}

Thermo-physical properties of foods play a great role in heat transfer calculations of food processing. Thermophysical properties of foods are included specific heat, enthalpy, thermal conductivity, thermal diffusivity and density. One of the most important thermo-physical properties in food processing is specific heat. Specific heat is an essential part of the thermal analysis of food processing or of the equipment used in heating or cooling of foods. In designing food processes and processing equipment, we need numerical values for the specific heat of the food and materials to be used [1]. The literature [2] specific heat is important engineering properties of a material related to heat transfer characteristics. The computation of refrigeration requirements and freezing times can be done only when quantitative information on food properties (specific heat) is available [3]. Specific heat data for different food materials below and above freezing were given in Rahman (1995) and Singh (1995). A vast amount of literature on specific heat of foods exists. However, the data tend to be scattered, and the composition and origin (variety, cultivar), processing conditions, and structure of the foods are often not well documented. This detracts from the value of the data [4]. Three ways to obtain value data of specific heat of food such as published data (literature), direct measurement (experiment) and predictive equation (prediction).

Predicting and modeling of the specific heat of food products was using mathematical models. Mathematical modeling is the most effective and economical method to determine such specific heat in food products (Sweat 1995). There is now a large literature that presents empirical data of specific heat of food, as well as literature on compositionbased approach to predict thermal properties of food $[5,6]$. Therefore, a composition based prediction method was used to obtain the specific heat of food models. A full understanding and prediction of the specific heat of foods and their dependence on composition, structure [4]. Specific heat of solids and liquids depends upon temperature but are not sensitive to pressure, as they are incompressible to all practical purposes. The relevant parameters in calculating $c_{p}$ are temperature, moisture content, and porosity for porous materials [7]. Databases of specific heat of fresh and minimally processed foods such as fruits, vegetables, grains, cereals, meat and dairy products may be found in the literature [4, $8-11]$. The $c_{p}$ unit is $\mathrm{kJ} / \mathrm{kg}{ }^{\circ} \mathrm{C}$ in the SI system.

The objective of this article was to review of the specific heat of food models as functions of temperature.

\section{Specific heat models}

Specific heat is a measure of the energy required to change the temperature of food by one degree. Therefore, the specific heat of foods can be used to calculate the heat load imposed on the refrigeration equipment by the cooling or freezing of foods and beverages [8]. Specific heat is [3] essential to determine the amount of energy required in the process of heating or cooling in agricultural products and [1] essential part of the thermal analysis of food processing or of the equipment used in heating or cooling of foods. The specific heat depends on the nature of the process of heat addition in terms of either a constant pressure process or a constant volume process. However, because specific heats of solids and liquids do not depend on pressure much, except extremely high pressures, and because pressure changes in heat transfer problems of agricultural materials are usually small, the specific heat at constant pressure is considered (Mohsenin, 1980) [12]. For temperatures above freezing, the prediction of the specific heat of food is relatively easy. If there is a phase change, such as in freezing, then the latent heat involved during the phase change must be incorporated. This is called the apparent specific heat. Below freezing point the calculation is more difficult.

The specific heats of foodstuffs depend very much on their composition. Knowing the specific heat of each component of a mixture is usually sufficient to predict the specific heat of the mixture (Sweat, 1995) [12]. In unfrozen foods, specific heat is relatively constant with respect to temperature. However, for frozen foods, there is a large decrease in specific heat capacity as the temperature decreases [8]. The apparent specific heat is obtained by differentiating the enthalpy of the frozen food (which includes both latent and sensible heat) with respect to temperature [4]. Apparent specific heat increases dramatically near the initial freezing temperature Heldman (1982). Composition data for foods may be found in the literature $[8,13]$ and can be obtained from sources such as Holland et al. (1991) and United States Department of Agriculture (USDA) (1975, 1996).

\section{Unfrozen food models}

In unfrozen foods, specific heat is relatively constant with respect to temperature. One of the earliest models to calculate specific heat was proposed by Siebel (1892) as, following equation for aqueous solutions such as vegetable and fruit juices or pastes (fruits moisture content above of $50 \%),[1,9,12,14]$ :

$$
c_{p}=0.837+3.349 X_{w},
$$

where $X_{w}$ is the water content expressed as a fraction.

Charm (1971) suggested the following model $[1,9]$ :

$$
c_{p}=2.093 X_{f}+1.256 X_{s}+4.187 X_{w},
$$

where $X$ is the mass fraction; and subscripts $\mathrm{f}$ is fat, $\mathrm{s}$ is nonfat solids, and w is water. Note that in Equation (2), the coefficients of each term on the right-hand side are specific heat values of the respective food constituents.

Heldman (1975) proposed an expression for heat-capacity calculation of foods, based on the composition $[12,1,15,16]$ :

$$
c_{p}=4.180\left(0.34 X_{c a}+0.37 X_{p}+0.4 X_{f a}+0.2 X_{a s}+1.0 X_{w}\right),
$$

Heldman and Singh (1981) proposed the following expression based on the components of a food product $[1,6]$ ( $h$ - carbohydrate; $p$ - protein; $f$ - fat; $a$ - ash; and $w-$ moisture):

$$
c_{p}=1.424 X_{h}+1.549 X_{p}+1.675 X_{f}+0.837 X_{a}+4.187 X_{w} .
$$

Mohsenin (1980) proposed an equation valid for the calculation of $c_{p}$ of meats, fruits, vegetables, and other foods, which equals the sum of the specific heat of water $c_{p w}$ and solid matter $c_{p s m}[9]$ :

$$
c_{p}=c_{p_{s m}}+\left(c_{p_{w}}-c_{p_{s m}}\right) x_{w} \text {. }
$$


Specific heat equations for food components $\mathbf{J} /(\mathbf{k g} \cdot \mathbf{K})^{\mathrm{a}}$ $\left(-40 \leq \mathrm{t} \leq 150{ }^{\circ} \mathrm{C}\right)$

\begin{tabular}{|c|c|l|}
\hline No & $\begin{array}{c}\text { Food } \\
\text { Component }\end{array}$ & \multicolumn{1}{|c|}{ Thermal Property Model } \\
\hline 1 & Protein & $c_{p}=2.0082 \times 10^{3}+1.2089 t-1.3129 \times 10^{-3} t^{2}$ \\
2 & Fat & $c_{p}=1.9842 \times 10^{3}+1.4733 t-4.8008 \times 10^{-3} t^{2}$ \\
3 & Carbohydrate & $c_{p}=1.5488 \times 10^{3}+1.9625 t-5.9399 \times 10^{-3} t^{2}$ \\
4 & Fiber & $c_{p}=1.8459 \times 10^{3}+1.8306 t-4.6509 \times 10^{-3} t^{2}$ \\
5 & Ash & $c_{p}=1.0926 \times 10^{3}+1.8896 t-3.6817 \times 10^{-3} t^{2}$ \\
6 & Water $^{\mathrm{b}}$ & $c_{w}=4.0817 \times 10^{3}-5.3062 t+9.9516 \times 10^{-1} t^{2}$ \\
7 & Water $^{\mathrm{c}}$ & $c_{w}=4.1762 \times 10^{3}-9.0864 \times 10^{-2} t+5.4731 \times 10^{-3} t^{2}$ \\
8 & Ice $_{9}$ & $c_{\text {ice }}=2.0623 \times 10^{3}+6.0769 t$ \\
9 & Air ${ }^{\mathrm{d}}$ & $c_{p \text { moist air }}=c_{p \text { dry air }}(1+8.37 \mathrm{RH})$ \\
\hline
\end{tabular}

${ }^{\text {a }}$ From Choi and Okos (1986);

${ }^{b}$ For the temperature range of $-40^{\circ} \mathrm{C}$ to $0^{\circ} \mathrm{C}$;

${ }^{\text {c }}$ For the temperature range of $0{ }^{\circ} \mathrm{C}$ to $150{ }^{\circ} \mathrm{C}$;

${ }^{\mathrm{d}}$ Riegel (1992), (RH-relative humidity)

Rahman (1993) correlated the excess specific heat for fresh seafood as

$$
c_{e x}=-33.77+85.58\left(X_{w}^{w}\right)-53.76\left(X_{w}^{w}\right)^{2} .
$$

In 1986, Choi and Okos developed specific heat of food components water, protein, fat, carbohydrate, fiber, and ash mathematical models for prediction of specific heat of these food components as functions of temperature in the range of $-40{ }^{\circ} \mathrm{C}$ to $150{ }^{\circ} \mathrm{C}$ (table) $[8,12]$.

The specific heat of a food, at temperatures above its initial freezing point, can be obtained from the mass average of the specific heats of the food components. Choi and Okos (1987) presented a comprehensive model to predict specific heat based on composition and temperature. Their model is as follows $[1,4-6,8-10,12,15-18]$ :

$$
c_{u}=\sum c_{i} x_{i}
$$

where $c_{i}$ is the specific heat of the individual food components and $x_{i}$ is the mass fraction of the food components.

A simpler model for the specific heat of an unfrozen food is presented by Chen (1985). If detailed composition data are not available, the following expression for specific heat of an unfrozen food can be used $[5,8]$ :

$$
c_{u}=4.19-2.30 x_{s}-0.628 x_{s}^{3},
$$

where $c_{u}$ is the specific heat of the unfrozen food in $\mathrm{kJ} /(\mathrm{kg} \cdot \mathrm{K})$ and $x_{s}$ is the mass fraction of the solids in the food. Wallapapan et al. (1983) recommend (when no other data are available and only for estimation purposes of specific heat of food materials) using the equations reported by ASHRAE as proposed by Seibel (1892) [3].

$$
c_{p}=0.200+0.008 x_{s} .
$$

Siebel's equation is used by the ASHRAE in one of the most comprehensive tabulated values for specific heat of foods model [10]. Seibel's equations have been found to agree closely with experimental values when $\mathrm{M}>0.7[10]$, the specific heat of fruits $M>0.5$ is used by Siebel (1982) model [14]. Specific heat of these food components, such as water, protein, fat, carbohydrate, fiber, and ash model developed by Choi and Okos (1986) are the lowest prediction error. Values for $c_{p}$ calculated using Choi and Okos' (1987) correlations, are generally higher than Siebel's equations $(M>0.7)$. Choi and
Okos' correlation is more accurate at low moisture contents. Choi and Okos' correlations are more accurate at low moisture contents and for a wider range of product composition (Macovei, 2000; Onița, 2004) [19]. Gratão and others (2004) used the Choi and Okos' model to predict specific heat of unfrozen passion fruit juice of various water contents at two temperatures and found the maximal \% error to be $3.24 \%$. Pham (1996) compared specific heat values provided by the Choi and Okos' model to those in literature for unfrozen meat, fish and vegetables. Based on his analysis, the correlation between measured values and predicted values was 0.6 , with $3.3 \%$ average $\%$ error. However, in Pham's analysis, the maximal \% error was $16 \%$, indicating that the model might have large deviations when applied to specific food products. Singh (1981) could predict the specific heat of food reasonably well. Heldman \& Singh model could predict the heat capacity of Cheddar cheese reasonably well with deviations of approximately $3.5 \%$ [6]. Standard error of estimation (SEE) of Choi and Okos' (1987) and Heldman \& Singh models are 0.110 and 0.126 at temperature $20{ }^{\circ} \mathrm{C}$ (Hanan H. Hamid et al.) [16].

\section{Frozen food models}

During the freezing process, water changes gradually from the liquid phase to solid ice. Since the properties of ice are different from those of liquid water, the properties of food determined at temperatures above freezing are often not valid for subfreezing conditions. The most dramatic change in these properties is observed at temperatures close to the freezing point. Therefore, the determination and modeling of specific heat of foods under frozen conditions requires explicit knowledge of the state of water in the foods [4]. The reason for the lower values of $c_{p}$ below freezing is that the specific heat of ice is about one half of that of the liquid water. This also partly explains the higher thawing times of foods as compared to their freezing times [12]. Below the food's freezing point, the sensible heat from temperature change and the latent heat from the fusion of water must be considered. Because latent heat is not released at a constant temperature, but rather over a range of temperatures, an apparent specific heat must be used to account for both the sensible and latent heat effects [8].

Siebel (1892) also suggested the following equation for food materials below their freezing point [12]:

$$
c_{p}=0.837+1.256 X_{w}^{w},
$$

where $X_{w}^{w}$ is the mass fraction of moisture within the sample and specific heat, and $c_{p}$ is given in $\mathrm{kJ} /(\mathrm{kg} \cdot \mathrm{K})$.

A common method to predict the apparent specific heat of foods is (Schwartzberg 1976) $[4,5,8]$ :

$$
\begin{aligned}
& c_{a}=c_{u}+\left(x_{b}-x_{w o}\right) \Delta c+ \\
& +E \cdot x_{s}\left[\frac{R \cdot T_{o}^{2}}{M_{w} T^{2}}-0.8 \Delta c\right],
\end{aligned}
$$

where $c_{a}$ is apparent specific heat, $c_{u}$ is specific heat of food above initial freezing point, $x_{b}$ is mass fraction of bound water, $x_{w o}$ is mass fraction of water above initial freezing point, $0.8=$ constant, $\Delta c$ is difference between specific heats of water and ice $=c_{w}-c_{i c e}, E$ is ratio of relative molecular masses of water $M_{w}$ and food solids $M_{s}\left(E=M_{w} / M_{s}\right), R$ is universal gas constant $=8.314 \mathrm{~kJ} /(\mathrm{kg} \mathrm{mol} \cdot \mathrm{K}), T_{o}$ is freezing point of water $=273.2 \mathrm{~K}, M_{w}$ is relative molecular mass, $\mathrm{kg} / \mathrm{kmol}, t$ is food temperature, ${ }^{\circ} \mathrm{C}$. 
The specific heat of the food above the freezing point may be estimated with Equation (7) or (8). Schwartzberg (1981) developed an alternative method for determining the apparent specific heat of a food below the initial freezing point, as follows $[4,5,8]$ :

$$
c_{a}=c_{f}+\left(x_{w b}-x_{b}\right)\left[\frac{L_{o}\left(t_{o}-t_{f}\right)}{t_{o}-t}\right],
$$

where $c_{f}=$ specific heat of fully frozen food (typically at $-40^{\circ} \mathrm{C}$ ), $t_{o}=$ freezing point of water $=0^{\circ} \mathrm{C}, t_{f}=$ initial freezing point of food, ${ }^{\circ} \mathrm{C}, t=$ food temperature, ${ }^{\circ} \mathrm{C}, L_{o}=$ latent heat of fusion of water $=333.6 \mathrm{~kJ} / \mathrm{kg}$.

A slightly simpler apparent specific heat model, which is similar in form to that of Schwartzberg (1976), was developed by Chen (1985a). Chen's model is an expansion of Siebel's equation (Siebel 1892) for specific heat and has the following form $[4,5,8]$ :

$$
c_{a}=1.55+1.26 x_{s}+\frac{x_{s} R \cdot T_{o}^{2}}{M_{s} T^{2}},
$$

where $c_{a}=$ apparent specific heat, $\mathrm{kJ} /(\mathrm{kg} \cdot \mathrm{K}), x_{s}=$ mass fraction of solids, $R=$ universal gas constant, $T_{o}=$ freezing point of water $=273.2 \mathrm{~K}, M_{s}=$ relative molecular mass of soluble solids in food, $t=$ food temperature, ${ }^{\circ} \mathrm{C}$.

When calculating the calculated specific heat of the frozen food $c_{p a}$, it is necessary to take into account the amount of water changes gradually from the liquid phase to solid ice, the specific heat of ice $c_{i}$. For frozen food, $c_{p a}$ has the following form $[17,18]$ :

$$
c_{p a}=c_{w} W(1-\omega)+c_{i} W \omega+c_{s}(1-W) .
$$

The moisture content of food products is between 0.50 and 0.96 the apparent specific heat can be computed as [20]:

$$
c_{p a}=1465.4+1482.7\left(W_{p}-W\right),
$$

where $W_{p}$ is the initial moisture content of food product, \%, $W$ - the lowest initial moisture content in the food products $(W=50 \%)$.

Another simple method can be used to determine specific heat [4]. This method is based on the relationship between specific heat and enthalpy and uses enthalpy data for determining specific heat. From this enthalpy data, the apparent specific heat at a given temperature can be determined using following Equation:

$$
c=\frac{1}{\rho} \cdot \frac{H_{T}-H_{-40}}{T-40} .
$$

Since for most practical food applications, $H_{-40}$ is assumed as zero, the above equation simplifies to [4]:

$$
c=\frac{1}{\rho} \cdot \frac{H_{T}}{T-40} .
$$

Wallapapan et al. (1983) recommend (when no other data are available and only for estimation purposes of specific heat of food materials) using the equations reported by ASHRAE as proposed by Seibel (1892) [3].

$$
c_{p}=0.200+0.003 x_{s} .
$$

Apparent specific heat model of Schwartzberg (1976) performed best. The two models by Schwartzberg $(1976,1981)$ performed similarly, exhibiting average absolute prediction errors of approximately $20 \%$ with large standard deviations of approximately $25 \%$. The method by Chen (1985a) produced a slightly larger average absolute prediction error of $20.5 \%$ with a standard deviation of $25.6 \%$. Of the three equations tested, the equation of Chen (1985a) is the easiest to use, although it produced the largest average absolute prediction error (Bryan R. Becker et al) [8, 21].

\section{Multifunctional models}

Specific heat of food was determined by using experimental data of thermal conductivity, thermal diffusivity and density (Hobani, Tolba 1995) [22]:

$$
c=\frac{\lambda}{\rho \cdot \alpha},
$$

where: $c$ - specific heat $\left(\mathrm{J} / \mathrm{kg}{ }^{\circ} \mathrm{C}\right) ; \alpha-$ thermal diffusivity $\left(\mathrm{m}^{2} / \mathrm{s}\right) ; \rho$ - bulk density $\left(\mathrm{kg} / \mathrm{m}^{3}\right)$.

\section{Conclusion}

In most food processing applications, we use specific heat at constant pressure specific heat $\left(c_{\mathrm{p}}\right)$, because of pressure changes in heat transfer problems of agricultural materials are usually small. Specific heat is one of the useful properties of the engineering and design of food processing devices. Prediction of the specific heat of food model is dependence on composition, structure and temperature. Seibel (1892) and Heldman and Singh (1981) models do not show the effect of temperature. The most widely used predicting the specific heat of food models are Choi and Okos (1987) and Schwartzberg 1976. Other widely used predicting the mathematical models are Seibel (1892), Chen (1985) and Heldman (1975).

\section{References}

1. R. Paul Singh, Dennis R. Heldman. Introduction to Food Engineering ( $4^{\text {th }}$ Edition). Academic Press, 2008, pp: 257-262.

2. Yang W., Sokhansanj S., Tang J., Winter P. Determination of Thermal Conductivity, Specific Heat and Thermal Diffusivity of Borage Seeds. Biosystems Engineering. 2002. 82 (2), p. 169-176.

3. Casanova, Pedro, Corrêa, Paulo C., Solís, Kattia, Campos, Julio C. C., Thermal properties of Conilon coffee fruits. IOSR Journal of Engineering. 2013, Vol. 3, Iss. 11. PP. 29-35.

4. M. A. Roa, Syed. S. H. Revzi, Ashim. K. Datta. Engineering Properties of Foods ( ( $^{\text {th }}$ Edition). 2005. pp: 175-201.

5. Brian A. Fricke, Bryan R. Becker. Evaluation of Thermo-physical Property Models for Foods. HVAC \& R Research. October 2001. Vol. 7, No. 4

6. Marschoun L. T., Muthukumarappan K., and Gunasekaran S. Thermal properties of cheddar cheese: experimental and modeling. International Journal of Food Properties, 2001, 4 (3), p. 383-403.

7. Kenneth J. Valentas, Enrique Rotstein, R. Paul Singh. Handbook of food engineering practice. CRC, New York, 1997, pp: 427456.

8. American Society of Heating, Refrigerating and AirConditioning Engineers, Inc. ASHRAE Handbook. Refrigeration (SI). 2010. pp: 284-300.

9. Handbook of food engineering, $2^{\text {nd }}$ edition. Edited by D. R. Heldman and D. B. Lund. 2007. pp: 398-403.

10. Romeo T. Toledo. Fundamentals of Food Process Engineering. Third Edition, 1999, pp. 125-152. 
11. World Food Logistics Organization, WFLO Commodity Storage Manual, Revised 2008.

12. Serpil Sahin, Servet Gülüm Sumnu. Physical Properties of Foods. Springer, New York, NY, 2006, pp: 107-153. DOI: https:// doi.org/10.1007/0-387-30808-3

13. Cengel Yunus, Ghajar Afshin. Heat and mass transfer, Fundamentals and Applications: 5 $^{\text {th }}$ edition, 2014, pp. 1149-1194.

14. Bambang Dwi Argo, Nur Komar, Retno Damayanti. Determination of Thermal Conductivity of Ambon Banana (Musa Paradisiaca L.) in One Dimensional Heat Transfer Mechanism. Journal of Agricultural Technology, Dec 2000, Vol. 1, No. 3. P. 9-16.

15. Lozano Jorge E. Fruit Manufacturing/Scientific Basis, Engineering Properties, and Deteriorative Reactions of Technological Importance. 2006. Springer pp: 73-94.

16. Hanan H. Hamid, Mark Mitchell, Amirreza Jahangiri, David V. Thiel, Experimental validation of new empirical models of the thermal properties of food products for safe shippin. Heat and Mass Transfe. April 2018. Vol. 54, Iss. 4. Pp. 1247-1256.

17. Filippov B. I., Kuprin D. A. Thermo-physical characteristics of food. St. Petersburg, State University of Refrigeration and Food Processing Technologies, 2004, 20 p. (in Russian). [Филиn- пов Б. И., Куприн Д. А. Теплофизические характеристики пищевых продуктов. СПБ: СПБГУНиПТ, 2004, 20 с.]

18. Baranenko A. V., Kutsakova V. E., Borzenko E. I., Frolov S. V. Examples and objectives of the refrigeration technology, Part 3, Fundamental of Thermophysics. 2004. 249 pp. (in Russian). [Бараненко А. В., Куцакова В. Е., Борзенко Е. И., Фролов С. В. Примеры и задачи по холодильной технологии, Часть 3. Теплофизические основы. 2004. 249 с.]

19. Oniţa N., Ivan E. Estimation of the specific heat and thermal conductivity of foods only by their classes of substances contents (water, proteins, fats, carbohydrates, fiber, and ash.). Scientifical Researches. Agroalimentary Processes and Technologies. 2005. Vol. XI. No. 1, p. 217-222.

20. Mohamad Frihat, Bassam Al-zgoul, Jehad Radaeh, Maen AlRashdan and Aymad H. Al Frahat. Estimation of food product freezing time. Buletinul Institutului Politehnic Din Iaşi, 2012. Tomul LVIII (LXII), Fasc. 4, p. 39-47.

21. Bryan R. Becker and Brian A. Fricke. Food thermophysical property models. Int. Comm. Heat Mass Transfer, 1999. Vol. 26, No. 5, pp. 627-636.

22. Somaye Akbari, Reza Amiri Chayjan. Moisture content modelling of thermal properties of persimmon (cv. 'Kaki'). Res. Agr. Eng. 2017, Vol. 63, No 2, p. 71-78. doi: 10.17221/3/2016-RAE

\section{Information about authors}

\section{Baranov Igor Vladimirovich}

D. Sc., Professor, Director of School of Biotechnology and Cryogenic Systems of ITMO University, 191002, Russia,

St. Petersburg, Lomonosov str., 9, ivbaranov@corp.ifmo.ru

\section{Сведения об авторах}

Баранов Игорь Владимирович

д. т. н, профессор, директор мегафакультета биотехнологий низкотемпературных систем Университета ИТМО, 191002, Санкт-Петербург, ул. Ломоносова, 9, ivbaranov@corp.ifmo.ru

\section{AyeTun}

Postgraduate Student of Faculty of Cryogenic Engineering of ITMO University, 191002, Russia, St. Petersburg, Lomonosov str., 9, ayetunitmo@gmail.com

\section{Ай Тун}

аспирант факультета низкотемпературной энергетики Университета ИТМО, 191002, Санкт-Петербург, ул. Ломоносова, 9, ayetunitmo@gmail.com

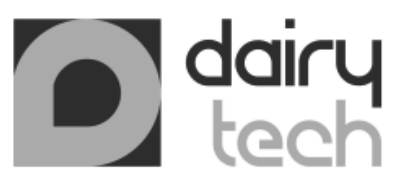

http://www.md-expo.ru

\section{8-я Международная выставка оборудования и технологий для молочного производства \\ DairyTech | Dairy \& Meat 2020}

\section{8-21 февраля 2020 г.}

Международная выставка оборудования и технологий для животноводства, молочного и мясного производств «DairyTech | Dairy \& Meat 2020» - это ведущее бизнес-мероприятие, демонстрирующее оборудование и технологии для агропромышленного производства полного цикла: от репродукции племенных животных, их выращивания, содержания и откорма до переработки и упаковки продукции животноводства: как для молочной индустрии, так и для мясной.

\section{РАЗДЕЛЫ ВЫСТАВКИ:}

* Оборудование и технологии для выращивания и содержания сельскохозяйственных животных;

* Оборудование и технологии для производства молока и молочной продукции;

* Оборудование для производства и розлива напитков.

Место проведения:

Россия, Москва, МВЦ «Крокус Экспо», павильон 1

http://www.crocus-expo.ru
Организатор выставки: ITE Москва +7 (499) 750-08-28, 750-08-30 md@ite-expo.ru www.ite-expo.ru 